\title{
Osteomyelitis: a current challenge
}

Authors

Luciana Souza Jorge, doctoral student $t^{1,2}$

Alceu Gomes Chueire, Professor $\mathrm{PhD}^{3,4}$

Andréa Regina Baptista Rossit, Professor PhD ${ }^{5,6}$

${ }^{1}$ Doctoral student of the Health Sciences Post Graduation Program,

Faculdade de Medicina de São José do Rio Preto (FAMERP), São Paulo, Brazil ${ }^{2}$ Infectologist of the Hospital Infection Control Service of Hospital de Base, Faculdade de Medicina de São José do Rio Preto (FAMERP), Brazil. ${ }^{3}$ Professor of the Orthopedics and Traumatology Department, Faculdade de Medicina de São José do Rio Preto (FAMERP), Brazil. ${ }^{4} \mathrm{Head}$ of the Orthopedics and Traumatology Service of Hospital de Base, São José do Rio Preto, São Paulo, Brazil. ${ }^{5}$ Professor $\mathrm{PhD}$ of the Department of Dermatologycal, Infectious and Parasitical Diseases, Faculdade de Medicina de São José do Rio Preto (FAMERP), São Paulo, Brazil.

${ }^{6} \mathrm{Head}$ of the Microbiology Section and responsible for the Research Center for Microorganism Investigations of FAMERP, São Paulo, Brazil.

Submitted on: 07/08/2009 Approved on: 12/10/2009

Correspondence to: Luciana Souza Jorge Rua das Figueiras, 53 Residencial Village Damha I, Mirassol - SP Brazil

CEP: 15130-000

Phone: + 55-17-32015700

E-mail: lucianasjorge@

uol.com.br

This study was financially supported by a research grant from BAP/FAMERP (2007-2008)

\begin{abstract}
Over the last 30 years, the pathogenesis of osteomyelitis has almost been totally elucidated, and many factors responsible for the persistence of this infection have been identified. Numerous antimicrobial agents with distinct spectrums of action, pharmacokinetics, and pharmacodynamics have been used in its treatment. Surgical techniques, including muscle grafts, the Ilizarov technique, and antibiotic bone cements, have been applied. However, bone infections are still a challenge. Despite the importance of isolation and identification of microorganisms to determine the antimicrobial treatment of bone infections, there are few systematic national studies about the etiological profile of these diseases. This article describes the current knowledge of osteomyelitis and summarizes published national data based on the experience of different Orthopedic and Traumatology Services. In general, S. aureus was described as an important etiological agent; however, the difference in design of national studies makes a comparison between the prevalence of bone infection, the associated risk factors, and the different therapeutic approaches difficult. In conclusion, effort is necessary in order to stimulate systematic national studies in different Orthopedics and Traumatology Services to obtain a better consensus on preventive measures and therapies of bone infections.
\end{abstract}

Keywords: osteomyelitis, arthroplasty, S. aureus.

[Braz J Infect Dis 2010;14(3):310-315] CElsevier Editora Ltda.

\section{INTRODUCTION}

Osteomyelitis is a progressive infection that results in inflammatory destruction, necrosis, and bone neoformation, which can progress to a chronic and persistent stage. ${ }^{1}$ However, it is not a single entity; this disease is differentiated according to the etiology, pathogenesis, and degree of bone involvement, as well as age and the immune condition of the patient. ${ }^{2}$ It can involve different structures such as the bone marrow, cortex, periosteum, and parts of the surrounding soft tissues, or remain localized. Given this heterogeneity, several methods of classification have been proposed. However, the models of Waldvogel et al. ${ }^{3}$ and of Cierny-Mader ${ }^{4}$ are the most accepted. Waldvogel's system is based on duration, mechanism of infection, and presence of vascular insufficiency, providing the following classification: a) acute hematogenic osteomyelitis; b) osteomyelitis by contiguity, with or without vascular inadequacy; c) vertebral osteomyelitis; and d) chronic osteomyelitis. ${ }^{3}$ On the other hand, the Cierny-Mader's classification is focused on the portion of the affected bone and the physiological state of the host, including local (chronic lymphedema, venous stasis, retained foreign bodies, etc.) and systemic risk factors (tobacco abuse, immune deficiencies, malnutrition, etc.). ${ }^{3-7}$ According to Sia \& Berbari. ${ }^{5}$ the latter classification has more evident clinical significance in treatment and prognosis of osteomyelitis, since it is more comprehensive, including considerations of other risk factors besides patient's bone injury. Regardless of the model adopted, the distinct types of osteomyelitis require different clinical and surgical therapeutic strategies. The most common bone infections in decreasing order are: osteomyelitis secondary to a contiguous-focus of infection or by direct inoculation (contamination after trauma or due to surgery); osteomyelitis due to vascular insufficiency and infection of surrounding soft tissues with the bone initially unaffected, including diabetic foot, and, finally, infections originating from the bloodstream in which the origin of the infection is distant. ${ }^{5,8}$ Bloodstream-sourced infections generally involve the metaphysis of long bones in children or 
vertebral bodies in adults. ${ }^{2,9,10}$ While the incidence of acute hematogenous osteomyelitis has been reducing in under 13 -year-old children, ${ }^{11,12}$ bone infections by direct inoculation have increased over the last decades. This is probably due to high-energy accidents and the growing use of orthopedic fixation devices and joint prostheses. ${ }^{13}$ When genders are compared, men present with a higher rate of contiguous-focus osteomyelitis. ${ }^{14}$ In fact, men are more frequently involved in automobile accidents, which tend to cause exposed fractures with consequent high rates of infection. ${ }^{15}$

\section{Microbial etiology of osteomyelitis}

Bone tissue is relatively resistant to infection. However, osteomyelitis may occur after a great inoculation of microorganisms or even by a small inoculation of particularly virulent bacteria. Thus, the occurrence, type, severity, and the prognosis of osteomyelitis depends on the inter-relationship of a triad composed of characteristics inherent to the infection, the host, and the infecting pathogen. ${ }^{12}$

Table 1 shows osteomyelitis according to the type, age/ susceptibility factors of the host, and microbial etiology. Hematogenous osteomyelitis is generally monomicrobial,

Table 1. Osteomyelitis according to type, age/susceptibility factors of the host and microbial etiology (in bold, the most frequent situation and isolated microorganisms)

\begin{tabular}{|c|c|c|}
\hline Types of osteomyelitis & Age/Susceptibility factors & Etiology \\
\hline \multicolumn{3}{|l|}{ Bloodstream-sourced } \\
\hline & Adults & Staphylococcus aureus \\
\hline & Newborn babies & Enterobacteriaceae, Streptococcus agalactiae \\
\hline & Children & $\begin{array}{l}\text { S. aureus, Streptococcus pyogenes, Group B } \\
\text { streptococci, Haemophilus influenzae }\end{array}$ \\
\hline & Sickle cell disease & Salmonella spp., S. aureus \\
\hline & Intravenous drug abuse & S. aureus, Pseudomonas. aeruginosa, Candida spp. \\
\hline \multicolumn{3}{|l|}{ Vertebral } \\
\hline & Adults & S. aureus \\
\hline & Urinary infection & Aerobic gram-negative bacilli, Enterococcus spp. \\
\hline & Injectable drug users & P. aeruginosa, S. aureus, \\
\hline & & Serratia marcescens \\
\hline & Spinal column surgery & Coagulase-negative staphylococci, \\
\hline & & S. aureus, aerobic gram-negative bacilli \\
\hline & Infection of vascular devices & Candida spp. \\
\hline & Endemicity & M. tuberculosis, Brucella spp. \\
\hline \multicolumn{3}{|l|}{ Contiguous-focus } \\
\hline & $\begin{array}{l}\text { Diabetes mellitus, vascular } \\
\text { insufficiency, contaminated } \\
\text { exposed fracture }\end{array}$ & $\begin{array}{l}\text { Polymicrobial: } S \text {. aureus, coagulase-negative } \\
\text { staphylococci, Streptococcus spp., Enterococcus } \\
\text { spp., gram-negative bacilli, anaerobic }\end{array}$ \\
\hline & Contamination of the soil & Clostridium spp., Bacillus spp., \\
\hline & & Stenotrophomonas maltophilia, \\
\hline & & $\begin{array}{l}\text { Nocardia spp., atypical mycobacteria, } \\
\text { Aspergillus spp., Rhizopus spp., Mucor spp. }\end{array}$ \\
\hline & Orthopedic fixation devices & $\begin{array}{l}\text { S. aureus, coagulase-negative staphylococcus, } \\
\text { Propionibacterium spp. }\end{array}$ \\
\hline & Human or animal bites & Pasteurella multocida, Eikenella corrodens \\
\hline & Foot lesion by sharp object or nail & P. aeruginosa \\
\hline & Previous periodontal infection & Actinomyces spp. \\
\hline & Hospitalization (nosocomial source) & Enterobacteriaceae, P. aeruginosa, Candida spp. \\
\hline \multicolumn{3}{|l|}{ Chronic } \\
\hline & Fractures & S. aureus \\
\hline & $\begin{array}{l}\text { Ischemic ulcers (diabetes mellitus; } \\
\text { sickle cell disease; malnutrition) }\end{array}$ & Gram-negative bacilli, anerobe bacteria \\
\hline
\end{tabular}

Adapted from Mackowiak et al., 1978, ${ }^{44}$ and Lew \& Waldvogel, $2004{ }^{8}$ 
that is, a single bacterial species is isolated at the infection site. ${ }^{3,16,17}$ Among newborn babies, the most common bacteria found in bone infections are Streptococcus agalactiae and Escherichia coli, while S. aureus, Streptococcus pyogenes, and Haemophilus influenzae predominate in children. The incidence of osteomyelitis by $\mathrm{H}$. influenzae has reduced after the introduction of routine active immunization during childhood. ${ }^{12} \mathrm{~S}$. aureus is the most common microorganism isolated in adults, while other pathogens are less frequently found including Enterococcus spp., Streptococcus spp., Pseudomonas aeruginosa, Enterobacter spp., Mycobacterium spp., anaerobes, and fungi, specifically Candida spp. ${ }^{10}$

In vertebral osteomyelitis, although $S$. aureus is the predominant agent, gram-negative bacilli are frequently detected and may originate from the urinary tract and via injected drugs. In this setting, the incidences of P. aeruginosa and Serratia marcescens are high. ${ }^{18,19}$ In contiguous-focus osteomyelitis, with a notable polymicrobial etiology, S. aureus and coagulase-negative staphylococci are most commonly isolated, corresponding to $75 \%$ of the etiological agents, ${ }^{3,16,17}$ as well as gram-negative bacilli and anaerobic organisms. High rate of nasal and skin colonization by S. aureus, immunity disorders, and irregular scaring of pre-existent wounds are important in infections involving diabetic foot. This is understandable, since the skin lesions caused by superficial fungal infections, most common in these patients, represent a bacterial entry. ${ }^{20}$

S. aureus is the typical pathogen responsible for both acute and chronic osteomyelitis by forming a biofilm, with potential to rapidly develop antimicrobial resistance and expression of virulence factors, regardless of patient's immune status. In these cases, surgical intervention is necessary to control the infection. This bacterium is a member of the normal flora of the human nasal cavity with, approximately, $20 \%$ of people within a population colonized by these microorganisms in a persistent manner, while another $60 \%$ are transiently colonized. ${ }^{21}$ Due to its high virulence, $S$. aureus may cause several diseases, from localized superficial infections, such as skin infections, to the most severe forms of bacteremia, such as septic arthritis, endocarditis, and septic shock syndrome. This situation becomes more complex with the emergence of multiple drug-resistant strains, in particular methicillin- and vancomycin-resistant strains that are endemic in hospital setting. In addition, community-acquired strains with reduced drug susceptibility or even resistant have been reported. ${ }^{22,23}$ Antimicrobial resistance results in a delay in specific therapy, increasing the risk of disease chronification and of periprosthetic infection. ${ }^{12}$

Infections subsequent to stabilization of fractures or implants of joint prostheses are devastating complications difficult to treat. Prosthetic implants, which alters the environment, including local immunity, favors bacterial invasion. After the trauma, lesions of soft tissues, with decreased vascularization surrounding the fracture site and delayed healing, are important. As for bone and/or osteoarticular grafts, the success depends on biointegration between the metal implant and the bone by the formation of a tissue interface of host cells. However, the same phenomenon of adhesion and cell growth is promoted by some bacteria, in particular S. aureus, which, due to competition, impair biointegration. Early diagnosis and aggressive treatment of post-traumatic and periprosthetic bone infections with antibiotics, debridement, and/or stabilization of the internal fixation are essential for the success of treatment. Thus, it is common for surgeons to be faced with the dilemma between treatment of infection, which may require implant removal, and treatment of bone (fracture) or osteoarticular disease, which, in turn, requires implant maintenance. ${ }^{13}$

Post-arthroplasty infections are difficult to diagnose and treat and are associated with high morbidity and substantial costs. Advanced microbiological methods and novel imaging examinations have contributed to improvements in this therapy. ${ }^{24}$ The incidence of post-arthroplasty infections is $1.5 \%$ to $2.5 \%$ for primary interventions; however, higher rates have been reported for revision surgeries (2\% to $20 \%) .{ }^{25} \mathrm{~A}$ consensual classification of periprosthetic infections has not been established yet, but they can be defined according to postoperative period in three types: earlyonset, delayed-onset, or late-onset. Early manifestations are defined by the emergence of signs and symptoms within the first three post-arthroplasty months, although some authors limit this period to the first two to four weeks. Delayedonset manifests between three months and two years, while late-onset evolves more than two years after surgery. ${ }^{26-28}$ In early- and delayed-onset infections, the microorganisms can colonize the implant by direct inoculation during surgical intervention, while late-onset infections generally appear via the bloodstream. ${ }^{27,29}$ S. aureus and S. epidermidis correspond to $65 \%$ of pathogens that cause these infections, although other agents may also reach the prosthetic surface. ${ }^{28,30}$ Hence, procedures performed close to the genito-urinary and gastrointestinal tracts are the source of gram-negative bacilli, enterococci, and anaerobic organisms; similarly, dental and gum treatment are the source to the dissemination of Streptococcus viridans, Peptococcus spp. and Peptostreptococcus spp., as well as pyogenic skin infections, the classical source of Streptococcus spp. ${ }^{31}$ Additionally, bone disease due to mycobacterial infections, multiple microbial infections, and infections caused by uncommon pathogens, such as Candida spp., Brucella spp., have been reported. ${ }^{27,32,33}$

\section{Clinical-epidemiological profile of osteomyelitis in Brazil}

Despite the importance of isolation and identification of microorganisms to determine antimicrobial treatment of bone infections, there are few systematic national studies on the etiological profile of these diseases. After an extensive review of publications in the Medline and SciELO databases, only nine articles published on this subject in Brazilian populations over the last 13 years were found. These works describe 
specific clinical situations particular to each of the Orthopedics and Traumatology Services. Thus, standardization of a treatment protocol for osteomyelitis remains a challenge.
Table 2 summarizes published national data related to bone infections after exposed fractures or consequent to arthroplasty (knee and hip) and the main clinical-epidemiological factors

Table 2. Main clinical-epidemiological factors of bone infections after trauma and arthroplasty according to data from different Orthopedics and Traumatology Services in the state of São Paulo

\begin{tabular}{|c|c|c|c|c|c|c|c|}
\hline $\begin{array}{l}\text { Author } \\
\text { (year) }\end{array}$ & $\mathbf{n}$ & $\begin{array}{l}\text { Fracture/ } \\
\text { Prosthesis }\end{array}$ & Period & Frequency & Risk factors & Infectious agent & Therapy \\
\hline $\begin{array}{l}\text { Lima } \\
\text { et al. } \\
2004\end{array}$ & 134 & $\begin{array}{c}\text { Exposed fractures } \\
\text { of the lower } \\
\text { limbs }\end{array}$ & $\begin{array}{l}02 / 1998 \\
05 / 2000\end{array}$ & $40.3 \%$ & $\begin{array}{l}\text { - Volume of } \\
\text { transfused blood } \\
\text { - ASA III } \\
\text { mmediate interna } \\
\text { fixation of bone } \\
\text { - Femur } \\
\text { - Open wound }\end{array}$ & al & $\begin{array}{c}\text { Surgical } \\
\text { debridement } \\
\text { and } \\
\text { antimicrobial } \\
\text { therapy }\end{array}$ \\
\hline $\begin{array}{l}\text { Muller. } \\
\text { et al } \\
2003\end{array}$ & 117 & $\begin{array}{c}\text { Exposed fractures } \\
\text { Diverse bones }\end{array}$ & $\begin{array}{l}2000 \\
2002\end{array}$ & $20.5 \% *$ & NE & $\mathrm{NE}^{* * *}$ & $\begin{array}{l}\text { Antimicrobial } \\
\text { therapy and } \\
\text { external fixation }\end{array}$ \\
\hline $\begin{array}{l}\text { Lima } \\
\text { et al. } \\
2001\end{array}$ & 46 & $\begin{array}{l}\text { Total hip } \\
\text { arthroplasty }\end{array}$ & $\begin{array}{l}1993 \\
1995\end{array}$ & $15.1 \%$ & $\begin{array}{l}\text { Operative time } \\
\text { greater than } \\
140 \text { minutes }\end{array}$ & $\begin{array}{c}\text { P. aeruginosa } \\
\text { Coagulase-negative } \\
\text { staphylococci } \\
\text { Morganella morgani } \\
\text { inetobacter calcoaceticus } \\
\text { Staphylococcus spp. } \\
\text { P. aeruginosa } \\
\text { E. coli }\end{array}$ & $\begin{array}{c}\text { Surgical } \\
\text { debridement }\end{array}$ \\
\hline $\begin{array}{l}\text { Rudelli } \\
\text { et al. } \\
2008\end{array}$ & 32 & $\begin{array}{l}\text { Total hip } \\
\text { arthroplasty }\end{array}$ & $\begin{array}{l}1989 \\
2000\end{array}$ & ๆ & P & $\begin{array}{c}\text { S. aureus } \\
\text { Coagulase-negative } \\
\text { staphylococci } \\
\text { Enterococcus faecalis } \\
\text { E. coli } \\
\text { Peptostretococcus spp. } \\
\text { Acinetobacter spp. } \\
\text { Streptococcus mitis }\end{array}$ & $\begin{array}{l}\text { One-stage } \\
\text { revision } \\
\text { with bone } \\
\text { graft } \\
\text { Empiric and } \\
\text { directed } \\
\text { antibiotic } \\
\text { therapy }\end{array}$ \\
\hline $\begin{array}{l}\text { Leonhardt } \\
\text { et al. } \\
2006\end{array}$ & 12 & $\begin{array}{l}\text { Total knee } \\
\text { arthroplasty }\end{array}$ & $\begin{array}{l}2003 \\
2004\end{array}$ & $8.3 \%$ & NE & $\begin{array}{l}\text { Oxacillin-sensitive } \\
\text { S. aureus } \stackrel{* * *}{ }\end{array}$ & $\begin{array}{l}\text { Revision of prosthesis } \\
\text { in two stages, } \\
\text { and after six } \\
\text { months of spacer } \\
\text { and antimicrobial } \\
\text { therapy }\end{array}$ \\
\hline $\begin{array}{l}\text { Queiroz } \\
\text { \& Luzo } \\
1996\end{array}$ & 250 & $\begin{array}{l}\text { Total knee } \\
\text { arthroplasty }\end{array}$ & $\begin{array}{l}01 / 1991 \\
06 / 1995\end{array}$ & $6 \%$ & $\mathrm{NE}$ & $\begin{array}{l}\text { S. aureus } \\
\text { Enterobacter spp } \\
\text { S. epidermidis } \\
\text { Klebsiella spp. } \\
\text { P. aeruginosa } \\
\end{array}$ & $\begin{array}{l}\text { Arthroplasty, } \\
\text { debridement } \\
\text { and maintenance } \\
\text { of the prosthesis, } \\
\text { arthrodesis, resection } \\
\text { f the prosthesis, use of } \\
\text { ement with gentamicin } \\
\text { and revision surgery }\end{array}$ \\
\hline
\end{tabular}

NE, not evaluated.

*Acute phase infection.

**Isolation of microorganisms at time of admittance, before surgical debridement.

****The only published data on sensitivity profile.

ๆ All patients underwent one-stage revision of loose and infected hip arthroplasty. 
involved, all of which were obtained in Orthopedics and Traumatology Services in the state of São Paulo. In general, S. aureus was described as an important etiological agent; however, the difference in national study designs makes comparison between prevalence of bone infection, associated risk factors, and different therapeutic approaches difficult. Only two studies referred to the frequency of post-fracture osteomyelitis, which ranged from $20.5 \%{ }^{15}$ to $40.3 \%{ }^{34}$ in different services. Lima et al. ${ }^{34}$ reported the following risk factors: volume of transfused blood, ASA level III clinical classification, immediate internal fixation of the bone, femur fractures, and the presence of an open wound. The microbiological profile of infections was not described in these studies. In respect to hip arthroplasties, a single study reported the infection rate of around $15 \%,{ }^{35}$ higher than the percentage described for arthroplasties of the knee ( $6 \%$ to $8 \%$ ) reported by two other groups. ${ }^{36,37}$ As for risk factors in hip arthroplasties, operative times greater than 140 minutes were identified as significant. ${ }^{35}$ Gram-positive cocci, with predominance of $S$. aureus, were the most commonly isolated microorganisms after arthroplasties of the knee and hip. ${ }^{36-38}$ In a single study, coagulase-negative staphylococci, Pseudomonas aeruginosa, and Acinetobacter calcoaceticus were equally implicated as etiological agents of infection after hip arthroplasties. ${ }^{35}$ In a different approach involving one-stage revision in 32 patients with loose and infected hip arthroplasties, Rudelli et al. (2008) ${ }^{39}$ found coagulase-negative staphylococci as the mainly isolated bacteria. On the other hand, a great diversity of Gram-negative bacteria (eleven different species - totaling $31.5 \%$ of all the agents isolated) was described by Cabrita et al. ${ }^{38}$ in infections after hip arthroplasties. For further information on bone infections data in Brazil, we do recommend two review articles on osteomyelitis diagnosis and treatment and also on infection following total knee joint arthroplasty by Lima \& Zumiotti (1999) ${ }^{40}$ and Lima et al. (2004), ${ }^{41}$ respectively.

The availability of surgical techniques and leadingedge bone devices, combined with more accurate diagnosis has provided better treatment and an increased life expectancy of patients with osteoarticular and multipletrauma diseases. In this regard, the incessant occurrence of bone infections is a motive of frustration for both surgeons and patients. ${ }^{8}$ Among the causes of this lack of success is the insufficient evidence that supports efficacious antimicrobial therapies for osteomyelitis. ${ }^{42}$ The choice of antibiotics, although limited by the sensitivity of etiological agents, should also be based on the choice of appropriate via of administration, safety of long-term use, and cost. ${ }^{43}$ The heterogeneity among populations of patients and the multiplicity of clinical and surgical therapeutic options were also reported as complications in the reduc- tion of bone infection rates. ${ }^{39}$ Hence, only a multidisciplinary approach of orthopedic surgeons, infectologists, radiologists, and vascular and plastic surgeons, as well as rheumatologists will improve therapeutic outcomes., ${ }^{3,24}$

In conclusion, effort is necessary in order to stimulate systematic national studies in different Orthopedics and Traumatology Services to obtain a better consensus on preventive measures and therapies of bone infections.

\section{ACKNOWLEDGEMENTS}

The authors wish to thank David Andrew Hewitt for revising the English version of this manuscript.

\section{REFERENCES}

1. Smith IM, Austin OMB, Batchelor AG. The treatment of chronic osteomyelitis: A 10 year audit. J Plast Reconstr Aesthet Surg 2006; 59:11-5.

2. Pineda C, Vargas A, Rodríguez AV. Imaging of osteomyelitis: current concepts. Infect Dis Clin N Am 2006; 20:789-825.

3. Waldvogel FA, Medoff G, Swartz MN. Osteomyelitis: a review of clinical features, therapeutic considerations and unusual aspects (first of three parts). N Engl J Med 1970; 282(4):198-206.

4. Cierny G III, Mader J. Adult chronic osteomyelitis. Orthopedics 1984;7(10):1557-64.

5. Sia IG, Berbari EF. Osteomyelitis. Best Pract Res Clin Rheumatol 2006;20(6):1065-81.

6. Cierny G III, Mader JT, Penninck JJ. A clinical staging system for adult osteomyelitis. Clin Orthop Relat Res 2003; (414):724.

7. Mader JT, Shirtliff M, Calhoun JH. Staging and staging application in osteomyelitis. Clin Infect Dis 1997; 25(6):1303-09.

8. Lew DP, Waldvogel FA. Osteomyelitis. Lancet 2004; 364(9431):369-79.

9. Lazzarini L, Mader JT, Calhoun JH. Osteomyelitis in Long Bones. J Bone Joint Surg Am 2004; 86-A(10):2305-18.

10. Calhoun JH, Manring MM. Adult Osteomyelitis. Infect Dis Clin North Am 2005; 19(4):765-86.

11. Blyth MJG, Kincaid R, Craigen MAC, Bennet GC. The changing epidemiology of acute and subacute haematogenous osteomyelitis in children. J Bone Joint Surg Br 2001; 83(1):99102.

12. Brady RA, Leid JG, Costerton JW, Shirtliff ME. Osteomyelitis: Clinical overview and mechanisms of infection persistence. Clinical Microbiology Newsletter 2006;28(9):65-72.

13. Schmidt AH, Swiontkowski MF. Pathophysiology of infections after internal fixation of fractures. J Am Acad Orthop Surg 2000; 8(5):285-91.

14. Gillespie WJ. Infection in total joint replacement. Infect Dis Clin North Am 1990; 4(3):465-84.

15. Müller SS, Sardenberg T, Pereira GJC, Sadatsune T, Kimura EE, Novelli Filho JLVB. Estudo epidemiológico, clínico e microbiológico prospectivo de pacientes portadores de fraturas expostas atendidos em hospital universitário. Acta Ortop Bras 2003; 11(3):158-69.

16. Waldvogel FA, Medoff G, Swartz MN. Osteomyelitis: A Review of Clinical Features, Therapeutic Considerations and Unusual Aspects (Second of Three Parts). N Engl J Med 1970; 282(4):260-6. 
17. Waldvogel FA, Medoff G, Swartz MN. Osteomyelitis: a review of clinical features, therapeutic considerations and unusual aspects (third of three parts). N Engl J Med 1970; 282(4):31622.

18. Holzman RS, Bishko F. Osteomyelitis in heroin addicts. Ann Intern Med 1971; 75(5):693-6.

19. Sapico FL. Microbiology and antimicrobial therapy of spinal infections. Orthop Clin North Am 1996; 27(1):9-13.

20. Calhoun JH, Cantrell J, Cobos J et al. Treatment of diabetic foot infections: Wagner classification, therapy, and outcome. Foot Ankle 1988; 9(3):101-6.

21. Kluytmans J, van Belkum A, Verbrugh H. Nasal carriage of Staphylococcus aureus: epidemiology, underlying mechanisms, and associated risks. Clin Microbiol Rev 1997; 10(3):505-20.

22. Lindsay JA, Holden MTG. Staphylococcus aureus: superbug, super genome? Trends Microbiol 2004; 12(8):378-85.

23. Pechous R, Ledala N, Wilkinson BJ, Jayaswal RK. Regulation of the expression of cell wall stress stimulon member gene msrA1 in methicillin-susceptible or -resistant Staphylococcus aureus. Antimicrob Agents Chemother 2004; 48(8):3057-63.

24. Esposito S, Leone S. Prosthetic joint infections: microbiology, diagnosis, management and prevention. Int J Antimicrob Agents 2008; 32(4):287-93.

25. Lentino JR. Prosthetic joint infections: bane of orthopedists, challenge for infectious disease specialists. Clin Infect Dis 2003; 36(9):1157-61.

26. Zimerli W, Ochsner PE. Management of infection associated with prosthetic joints. Infection 2003; 31(2):99-108.

27. Zimmerli W, Trampuz A, Ochsner PE. Prosthetic-joint infections. N Engl J Med 2004; 351(16):1645-54.

28. Trampuz A, Widmer AF. Infections associated with orthopedic implants. Curr Opin Infect Dis 2006; 19(4):349-56.

29. Berbari EF, Hanssen AD, Duffy MC et al. Risk factors for prosthetic joint infection: case-control study. Clin Infect Dis 1998; 27(5):1247-54.

30. Sia IG, Berbari EF, Karchmer AW. Prosthetic joint infections. Infect Dis Clin North Am 2005; 19(4):885-914.

31. Barberan J. Management of infections of osteoarticular prosthesis. Clin Microbiol Infect 2006; 12 Suppl 3:93-101.
32. Weil Y, Mattan Y, Liebergall M, Rahav G. Brucella prosthetic joint infection: a report of 3 cases and a review of the literature. Clin Infect Dis 2003; 36(7):e81-6.

33. Marculescu CE, Berbari EF, Cockerill III FR, Osmon DR. Fungi, mycobacteria, zoonotic and other organisms in prosthetic joint infection. Clin Orthop Relat Res 2006; 451:64-72.

34. Lima ALLM, Zumiotti AV, Uip DE, Silva JS. Fatores preditivos de infecção em pacientes com fraturas expostas nos membros inferiores. Acta Ortop Bras 2004; 12(1):32-9.

35. Lima ALLM, Barone AA. Infecções hospitalares em 46 pacientes submetidos a artroplastia total do quadril. Acta Ortop Bras 2001; 9(1):36-41.

36. Queiroz AAB, Luzo MVM. Tratamento das infecções nas artroplastias totais de joelho. Rev Bras Ortop 1996; 31(5):366-8.

37. Leonhardt MC, D’Elia CO, Santos ALG, Lima ALLM, Pécora JR, Camanho GL. Revisão da artroplastia total de joelho em dois tempos: o valor da cultura obtida por biópsia artroscópica. Acta Ortop Bras 2006; 14(4):226-8.

38. Cabrita HB, Croci AT, Camargo OP, Lima ALLM. Prospective study of the treatment of infected hip arthroplasties with or without the use of an antibiotic-loaded cement spacer. CLINICS 2007; 62(2):99-108.

39. Rudelli S, Uip D, Honda E, Lima ALLM. One-stage revision of infected total hip arthroplasty with bone graft. J Arthroplasty 2008; 23(8):1165-1177.

40. Lima ALLM \& Zumiotti AV. Aspectos atuais do diagnóstico e tratamento das osteomielites. Acta Ortop Bras 1999; 7(3): 135142.

41. Lima ALLM, Pécora JR, Albuquerque RM et al.. Acta Ortop Bras 2004; 12(4): 236-241.

42. Stengel D, Bauwens K, Sehouli J, Ekkernkamp A, Porzsolt F. Systematic review and meta-analysis of antibiotic therapy for bone and joint infections. Lancet Infect Dis 2001; 1(3):175-88.

43. Lazzarini L, Lipsky BA, Mader JT. Antibiotic treatment of osteomyelitis: what have we learned from 30 years of clinical trials? Int J Infect Dis 2005; 9:127-38.

44. Mackowiak PA, Jones SR, Smith JW. Diagnostic value of sinus-tract cultures in chronic osteomyelitis. JAMA 1978; 239(26):2772-5. 